\title{
Dynamic Impact of Unconventional Monetary Policy on International REITs
}

\author{
Hardik A. Marfatia ${ }^{1}$, Rangan Gupta ${ }^{2, *(D)}$ and Keagile Lesame ${ }^{2}$ \\ 1 Department of Economics, Northeastern Illinois University, BBH 344G, 5500 N. St. Louis Ave., \\ Chicago, IL 60625, USA; h-marfatia@neiu.edu \\ 2 Department of Economics, University of Pretoria, Pretoria 0002, South Africa; keagilel@gmail.com \\ * Correspondence: rangan.gupta@up.ac.za
}

Citation: Marfatia, Hardik A. Rangan Gupta, and Keagile Lesame. 2021. Dynamic Impact of Unconventional Monetary Policy on International REITs. Journal of Risk and Financial Management 14: 429. https://doi.org/10.3390/jrfm14090429

Academic Editor: Stephen Satchell

Received: 12 July 2021

Accepted: 27 August 2021

Published: 8 September 2021

Publisher's Note: MDPI stays neutral with regard to jurisdictional claims in published maps and institutional affiliations.

Copyright: (C) 2021 by the authors. Licensee MDPI, Basel, Switzerland. This article is an open access article distributed under the terms and conditions of the Creative Commons Attribution (CC BY) license (https:// creativecommons.org/licenses/by/ $4.0 /)$.

\begin{abstract}
In this paper, we estimate the dynamic impact of unconventional monetary policy in the US on international REITs. Unlike existing studies which are limited to conventional policy tools and undertake a static approach, we use an event study approach and estimate a time-varying parameter model to investigate the dynamic impact of forward guidance (FG) and large-scale asset purchases (LSAP) shocks on the international REIT returns. We also compare the effects of these unconventional tools with the effects of conventional federal funds rate (FFR) shocks. The results show that the response of international REITs to unconventional policy shocks depends on the time under consideration. FG shocks have greater time-variation in the impact on REIT returns compared to LSAP shocks, particularly with Australia, Belgium, and the US REIT markets. Furthermore, FG shocks broadly have a negative impact on REITs while the results for LSAP effects are mixed. We also find that in most countries, REITs time-varying response of FG shocks is related to changes in gold prices and financial conditions.
\end{abstract}

Keywords: unconventional monetary policy; forward guidance; LSAP; REITs; time varying parameter model

JEL Classification: E44; E52; C32; F42; G14

\section{Introduction}

The role of monetary policy in affecting the housing markets was central in the recent global financial crisis and the following recovery. The Federal Open Market Committee (FOMC) cut its key policy rate, the federal funds rate, to near-zero levels (often referred to as the zero lower bound or ZLB conditions) in its 16 December 2008 meeting. These conditions led to the adoption of unconventional monetary policy tools to further support economic recovery. These tools-forward guidance (FG) and large-scale asset purchase programs (LSAP) -impacted global financial markets, including real estate markets. This paper estimates the dynamic impact of US unconventional monetary policy on international REITs, and also contrasts it with the effects of conventional monetary policy.

Forward guidance is an explicit announcement of the likely future path of the federal fund rate. LSAP involves the announcement of large-scale purchases of long-term US treasuries and mortgage-backed securities to lower long-term interest rates. The transmission of US monetary policy shocks to international financial markets is well documented in the literature as global financial and economic linkages increased, see Sahoo et al. (2020) and Chian (2020) for more recent evidence. This paper contributes to this line of inquiry by investigating the dynamic effects of both US unconventional and conventional monetary policy on global REITs and to the best of our knowledge, this is the first paper to study the time-varying nature of this relationship for both conventional and unconventional US monetary policy effects. 
US monetary policy shocks induce co-movement in international financial market asset prices, Miranda-Agrippino and Rey (2020). Unconventional monetary policy shocks are transmitted to financial markets, including REITs through the signaling and portfolio re-balancing channels. These are both subsumed in the interest rate channel. The signaling channel operates by influencing investors' expectations about the future path of interest rates, which is what FG is intended to achieve. LSAP also has significant signaling effects that reduce future short-term interest rates, Bauer and Rudebusch (2014). The portfolio rebalancing channel refers to the purchase of long-term securities by central banks, which reduces the supply of bonds in the secondary market, leading to an increase in bond prices and a fall in bond yields. As a result, investors will adjust their portfolios by buying alternative assets, such as equities and REITs, in search for higher returns (Gagnon et al. 2011; Bauer and Neely 2014).

The global REIT market has experienced substantial growth with a market capitalization value of USD 1.7 trillion in 2016 from USD 734 billion in 2010 (Global REITs Market, EY Global Real Estate Report, 2016). Growth in the international REIT market and trading of REITs follows institutional changes in the 1990s which involved changes to the regulatory framework which allowed the use of internal advisors or self-managed REITs which made REIT companies more operations-oriented. The behavior of REIT stocks is more like general stocks Chan et al. (2005) however because their value is derived from the underlying real estate, monetary policy surprises which affect rental incomes of real estate companies also affect REIT prices, Chou and Chen (2014).

Existing literature that estimates the impact of monetary policy on international REIT markets is limited to either conventional tools or the use of a static approach. For example, Marfatia et al. (2017) use the federal funds futures rate as a proxy for market expectations of changes in US monetary policy and test the dynamic impact of unexpected US monetary policy surprises on global REITs. They found that the effect of US monetary policy on global REITs varied widely across time and between countries. Earlier work by (Xu and Yang 2011) using seemingly unrelated regressions (SUR) found that REIT returns for 18 developed countries responded positively to unexpected cuts in the federal funds rate, as well as downside surprises to the future path of federal fund rate (also see Ghysels et al. 2013; Akinsomi et al. 2016).

Other studies are limited to the use of a static approach. Gupta and Marfatia (2018) explored the response of REIT returns in emerging markets to unconventional US monetary policy shocks measured as a binary indicator variable, which takes the value of one in the month of a quantitative easing (QE) announcement and zero otherwise, and estimated a qualitative VAR model which combines this binary information of the US Fed's QE. Huber and Punzi (2018) estimated time-varying impulse responses with stochastic volatility of unconventional monetary policy effects, measured using shadow short rates by (Krippner 2013), on house prices and mortgage lending in the US, UK, Japan, and Euro area. Other studies that focus on unconventional monetary policy use a static approach including Swanson (2021) and Gabriel and Lutz (2017). However, understanding the response of international REITs to these new unconventional policy tools is at least, if not more, important than the conventional tool and how these effects evolve. We estimate the response of REIT returns to FG and LSAP policy decisions and also contrast it to the effects of the conventional tool-the FFR. In line with many studies in the literature, we use an event study approach, looking at changes in the returns of international REITs over a one-day window on the FOMC announcement following their meetings. ${ }^{1}$

Our results broadly suggest that conventional monetary policy shocks (FFR) had a stronger impact on international REITs than unconventional monetary policy shocks (FG and LSAP). This is also consistent with findings by (Feldkircher and Huber 2018) who found that conventional US monetary policy effects were persistent while QE effects were short-lived and only effective during the period of the global financial crisis. This possibly reflects the case that unconventional monetary policy was increasingly better anticipated by markets as economies and international financial markets recovered and stabilized after the 
great financial crisis. Haldane et al. (2016) showed that the effectiveness of asset purchases is state-contingent, that is the impact of the FOMC's QE on US financial markets including equities was larger when markets were more stressed between 2008 and 2010 compared to when market conditions improved relatively post 2010, also see, Hesse et al. (2018).

Focusing on unconventional monetary policy, the impact of FG and LSAP on international REITs varies by region. FG, aimed at lowering interest rates for the 2008 to 2014 period, had a negative impact on REIT returns for Asian countries in line with expectations based on the signaling channel. European REITs were mostly less responsive to dynamic FG shocks. The effect of LSAP was largely mixed, European REIT returns increased as the FOMC expanded its asset purchase program consistent with predictions of the portfolio balance channel. Although for most Asian markets in the sample, a positive LSAP is associated with a decline in REIT returns.

The paper contributes to the literature in multiple ways. First, this is the first paper to explore the dynamic impact of FG and LSAP on international REIT returns. Second, most existing studies focus on a single or few REIT markets. In contrast, we include REIT markets that make $96.2 \%$ of the global REIT index based on market capitalization (EPRA 2016). This brings the most comprehensive analysis of the impact of monetary policy on international REITs. Third, in contrast to existing literature that focuses on a static impact or only a special case of time variation, our modeling approach is flexible to uncover the gradual impact of monetary policy shocks at each point in time. This increases the precision of estimates and provides a finer view of the impact. Fourth, we also explore the relationship between the time-varying impact of FG and LSAP and an explanation of the impact.

\section{Methodology and Data}

\subsection{Methodology}

In estimating the precise impact of monetary policy on international REIT returns, one of the main challenges is to control the joint influence of several other macroeconomic variables that potentially affect real estate markets. To tackle this problem of joint effects, we use the widely accepted event study approach popular in the literature (Bernanke and Kuttner 2005; Cook and Hahn 1989; Hausman and Wongswan 2011; Kishor and Marfatia 2013; Marfatia 2014, 2015; Marfatia et al. 2017; among others). We use a one-day event window on the FOMC meeting day.

The approach has several advantages. First, it addresses the endogeneity issue, which can particularly be problematic in international markets. Second, it eliminates the risk that other events might influence REIT markets in a wider window. Third, it captures the forward-looking nature of unconventional monetary policy announcements. Following this popular conventional Cook and Hahn (1989) style approach, we study the effects of unconventional monetary policy in the US on international REIT returns.

In the past three decades, the international REIT markets and particularly the unconventional policy tools effect has witnessed significant structural changes. During this time period, every international REIT market has evolved in its sophistication and maturity. ${ }^{2}$ Moreover, the role of US monetary policy on the international platform has also evolved in the last 30 years (Hausman and Wongswan 2011; Kishor and Marfatia 2013; Marfatia 2014). It is no surprise then that studies find that factors that explain the movements in the REIT market differ greatly in the turbulent times as compared to normal periods (Ghysels et al. 2013; Akinsomi et al. 2016).

The existing evidence indicates that there are significant structural changes in the relationship between monetary policy and real estate markets (Ghysels et al. 2013; Akinsomi et al. 2016; Marfatia et al. 2017). Therefore, a static approach (such as standard regression models) is inadequate because it only captures the overall mean effect across time. A more sophisticated approach is needed to capture the dynamic impact of monetary policy.

We adopt a time-varying parameter (TVP) framework to estimate the precise dynamic impact of monetary policy on international REITs across time. The TVP model has the 
advantage of flexibly, as well as clearly discerning the impact of monetary policy over time. Our approach to combine event study within time-varying parameter (TVP) framework also has the advantage of being robust to small sampling perturbations.

For every (i) country, we estimate

$$
R_{t}^{i}=\beta_{0 t}^{i}+\beta_{1 t}^{i} M P_{t}+e_{t}^{i} \text { where, } e_{t}^{i} \sim N\left(0, \sigma_{e}^{i}\right)
$$

where, $R_{t}^{i}$ is the REIT return of country $i$ at time $t$, and $M P_{t}$ is the monetary policy shock at time $t$. We consider both conventional (FFR) and unconventional (FG and LSAP) policy shocks separately. Our parameter of interest is $\beta_{1 t}^{i}$. It captures the time-varying impact of monetary policy shocks on international REIT returns. The direction of impact (the sign of $\beta_{1 t}^{i}$ ) can be negative (borrowings channel) or positive (signaling channel) depending on the channel through which monetary policy shocks impact REITs across the globe.

$$
R_{t}^{i}=\left[\begin{array}{ll}
c & M P_{t}
\end{array}\right]\left[\begin{array}{l}
\beta_{0 t}^{i} \\
\beta_{1 t}^{i}
\end{array}\right]+e_{t}^{i}
$$

We follow the pioneering work of (Cooley and Prescott 1976) to model time-variation and assume $\beta_{t}^{i}$ to follow a random walk process. This allows us to capture capture various forms of non-linearity (Lubik and Matthes 2015). The transition equation representing the evolution of the unobserved state vector is then given by:

$$
\begin{gathered}
\beta_{t}^{i}=\beta_{t-1}^{i}+v_{t}^{i} \text { where, } v_{t}^{i} \sim N(0, Q) \\
{\left[\begin{array}{l}
\beta_{0 t}^{i} \\
\beta_{1 t}^{i}
\end{array}\right]=\left[\begin{array}{ll}
1 & 0 \\
0 & 1
\end{array}\right]\left[\begin{array}{l}
\beta_{0 t-1}^{i} \\
\beta_{1 t-1}^{i}
\end{array}\right]+\left[\begin{array}{l}
v_{0 t} \\
v_{1 t}
\end{array}\right]}
\end{gathered}
$$

Here, $Q$ is the variance-covariance matrix of the uncorrelated disturbance terms. The Kalman filter is applied to the above state-space model and the parameters are estimated using maximum likelihood.

\subsection{Data}

The dataset for the study includes 11 leading REIT markets for the period July 1991 to October 2015 at a daily frequency. We use the event study approach to analyze the impact of each monetary policy event for which the data are available. The 11 leading REIT markets constitute $96.2 \%$ of the global REIT index based on market capitalization. These 11 markets include Australia (7.47\%), Belgium (0.57\%), Canada $(2.95 \%)$, Germany $(0.19 \%)$, France $(1.93 \%)$, Hong Kong $(1.58 \%)$, Japan $(7.43 \%)$, Netherlands $(2.64 \%)$, Singapore (1.68\%), the UK (4.58\%), and the US (65.19\%) (European Public Real Estate Association, 2016). These countries are also defined as 'established and mature markets' based on the following 9 different criteria: capital flows, financial reporting, corporate governance, risk management, regulatory environment, cross-border issues, transaction activity, financing, and property specifics (EY Global perspectives: 2016 REIT report). The only exception is Belgium, which is classified as emerging as per these criteria.

Unlike most studies that focus on one or few international REIT markets, the present study thus covers almost the entire international REIT market. The study provides the most comprehensive analysis of the impact of unconventional monetary policy on REIT returns. This is also another contribution of the present study. The REITs data are sourced from the DataStream database of (Refinitiv 2020), with the real estate data corresponding to the S\&P REITs indices for each country.

Table 1 provides a preliminary overview of the data. The summary statistics show that France and the UK have the highest average REIT returns at $0.51 \%$ each followed by the Netherlands $(0.27 \%)$ and the US $(0.21 \%)$. The US which has the largest REIT market had the highest maximum and minimum return values in the sample at $13.35 \%$ and $-21.95 \%$, respectively. Only three countries registered negative average returns over the sample horizon, the Asian markets of Australia, Hong Kong, and Japan. German REITs had the 
largest dispersion from the mean at 3.62 followed by the UK and the US at 2.55 and 2.44, respectively, suggesting that these REITs were relatively risky than others such as Belgium, Australia, and the Netherlands which had relatively low standard deviations. Asian-Pacific REITs also have low median values.

Table 1. Summary statistics. The table presents summary statistics of the 11 leading international REIT returns.

\begin{tabular}{cccccccc}
\hline Country & Code & Mean & Median & Max. & Min. & S.D. & Obs \\
\hline Australia & AU & -0.080 & 0.000 & 4.419 & -11.097 & 1.454 & 213 \\
Belgium & BE & 0.173 & 0.157 & 6.403 & -7.574 & 1.383 & 172 \\
Canada & CA & 0.196 & 0.127 & 6.867 & -8.487 & 1.532 & 165 \\
Germany & DE & 0.202 & 0.401 & 7.387 & -16.128 & 3.619 & 69 \\
France & FR & 0.507 & 0.392 & 4.684 & -4.922 & 1.731 & 103 \\
Hong Kong & HK & -0.220 & 0.000 & 3.122 & -10.061 & 1.502 & 97 \\
Japan & JP & -0.308 & -0.116 & 7.892 & -8.506 & 2.073 & 120 \\
Netherlands & NL & 0.270 & 0.251 & 8.621 & -7.539 & 1.485 & 213 \\
Singapore & SG & 0.063 & 0.089 & 5.710 & -7.869 & 1.575 & 105 \\
UK & UK & 0.509 & 0.457 & 7.696 & -9.179 & 2.550 & 76 \\
USA & US & 0.216 & 0.079 & 13.347 & -21.945 & 2.441 & 213 \\
\hline
\end{tabular}

The data for unexpected changes in conventional and unconventional monetary policy are from (Krippner 2013). This includes surprise changes in the FFR, FG, and LSAP announcements. The exchange rate, gold price, treasury spread between 10-year and 3-month maturity, TED spread, corporate bond spreads, and the VIX used to explain the time variation are sourced from (Refinitiv 2020). We consider the exchange rate of the country with the US dollar, and in the case of the US, we use the trade-weighted US dollar index.

\section{Empirical Results}

\subsection{Dynamic Impact of Unconventional Monetary Policy}

Figures 1-3 presents the time-varying impact of surprise changes in Federal funds rate (FFR), forward guidance (FG), and large-scale asset purchases (LSAP), respectively, on international REIT returns in each of the 11 countries. The results provide further evidence of the time-varying nature of monetary policy shocks (conventional and unconventional) on international REITs, a dynamic that is not captured by fixed parameter models. Secondly, the impact of US monetary policy on global REITs varies across countries.

The evidence suggests that the impact of FFR surprises on REITs is relatively larger than the effect of unconventional monetary policy shocks in most of the countries except the US where unconventional monetary policy surprises tended to be relatively larger which is similar to findings by (Claus et al. 2014) who showed that the response of US REITs was larger when short-term interest rates were at the zero lower bound. This possibly reflects both the signaling channel (positive coefficient) or the borrowings channel (negative coefficient) effects.

The results in Figure 1 show that the response of REIT returns to FFR shocks is largely positive in Japan, Singapore, and Australia and the European countries of Belgium, Germany, and France. Notably, the FFR impact is relatively larger in the post-global financial crisis (GFC) period in Belgium, Australia, Germany, and Japan. A surprise increase (decrease) in the FFR led to an increase (decrease) in REIT returns. Thus, FFR shocks in these cases work through the signaling channel with interest rate increases signaling the FOMC's assessment of an expected stronger US economic conditions which could influence investor's own expectations of economic conditions in their respective countries supporting a favorable outlook on real estate demand or higher rental incomes of the underlying property portfolio, boosting the prospective profitability, and dividend payments of traded real estate companies. These findings are also consistent with the findings of (Marfatia et al. 2017) who found mostly positive time-varying effects of conventional US 
monetary policy surprises on REIT returns in Japan, France, Belgium, and Australia. In the cases of both Belgium and Australia, the effect was positive from 1999 to the end of the sample period compared to a mostly negative effect from the beginning when the sample began in 1995-1999. Gray (2013) showed that a large part of monetary policy shocks in other countries (including the Eurozone and Australia) can be explained by US monetary policy innovations and the implications thereof are that these central banks likely magnify the effects of US monetary policy on general liquidity conditions which could extend to their respective real estate markets. Marfatia et al. (2017) also found a negative of FFR on Canadian REITs. In the US, we find the borrowings channel to be more dominant. A surprise rate hike (cut) reduces (increases) the US REIT returns and these results are in line with evidence from Bredin et al. (2010) and Chou and Chen (2014) of a negative relationship between conventional US monetary policy and REIT returns. A higher (lower) policy rate has corresponding effects on the cost of borrowing, and, consequently, it negatively impacts REIT returns. Moreover, the impact of FFR on US REITs during the post-crisis period was steadily relative to pre-crisis and during crisis periods possibly due to the fact that its US interest rates were expected to remain at the zero lower bound for longer as the economy emerged from the crisis.

US unconventional monetary policy innovations have been found to have a statistically significant impact on the international REIT returns (Gabriel and Lutz 2017; Ghysels et al. 2013). Expansionary unconventional monetary policy lowers housing mortgage rates leading to higher REIT returns, therefore, it is expected that FG surprises which created expectations that rates short-term rates will remain low for longer than expected will boost REIT returns (interest rate channel). Alternatively, that could also signal a subdued economic outlook which is associated with lower expected housing demand affecting house prices leading to a drop in REIT returns through its signaling effect. On the other hand, a positive LSAP or an expansion of asset purchases, for example, would lower long-term interest rates. This reduces mortgage rates and boosts REIT returns.

However, unlike conventional monetary policy (FFR), identifying the response of REIT returns to FG and LSAP (unconventional monetary policy) is not immediately identifiable because FG also contains information about asset purchases (LSAP). Swanson (2021) builds on the high-frequency approach of Gürkaynak et al. (2005) and looks at the 30-min window responses of asset prices to FOMC's policy announcements to determine the immediate causal effects of those announcements. The author then tests for the number of dimensions underlying those announcements using principal component analysis. The effects of monetary policy announcements on asset prices during the period 1991-2015 is well described by three dimensions corresponding to changes in FFR, FG, and LSAPs. The author found that during the period in which US Fed rate was at the zero lower bound, FG had a negative and statistically significant effect on stock prices while the effect of unexpected LSAP announcements was positive but not statistically significant.

FG shocks (Figure 2), which is the FOMC's communication on the future path of policy rate had larger time variation than LSAP shocks (Figure 3). These variations are particularly pronounced in the case of the US during and after the 2008-2009 GFC period. We find that the impact of FG on REIT returns is mostly negative across the various countries in the sample in both the crisis and post-crisis periods, suggesting the signaling effect is more at play. Moreover, FG shocks are associated with larger declines in REIT returns during the GFC compared to the period after the GFC with the exception of the Netherlands where returns briefly increased during the GFC. Interestingly, in Canada, the REIT return coefficient is steady mostly throughout the sample period except for a momentary period where the coefficient sharply declines a few years before the year 2000. Swanson (2021) also found a negative relationship between FG and stock prices. One reason for this could be the timing of unconventional monetary policy. Between December 2008 and December 2012, before the US Fed formerly announced plans to taper its asset purchases in December 2013, FG emphasized keeping the federal funds rate at exceptionally low levels for longer (near zero) due to prevailing weak economic conditions (Smith and Becker 2015). These 
findings broadly suggest the signaling channel is more at play with FG signaling subdued economic growth conditions, influencing investors' own economic growth expectations reflected in changes in asset prices in the same direction. This is also consistent with evidence by Nakamura and Steinsson (2018) which showed that FOMC's assessment of economic outlook also influences the private sector's forecasts of economic conditions. Moreover, Batrancea et al. (2020) also argued the key role of monetary policy as a conduit to the growth outlook.
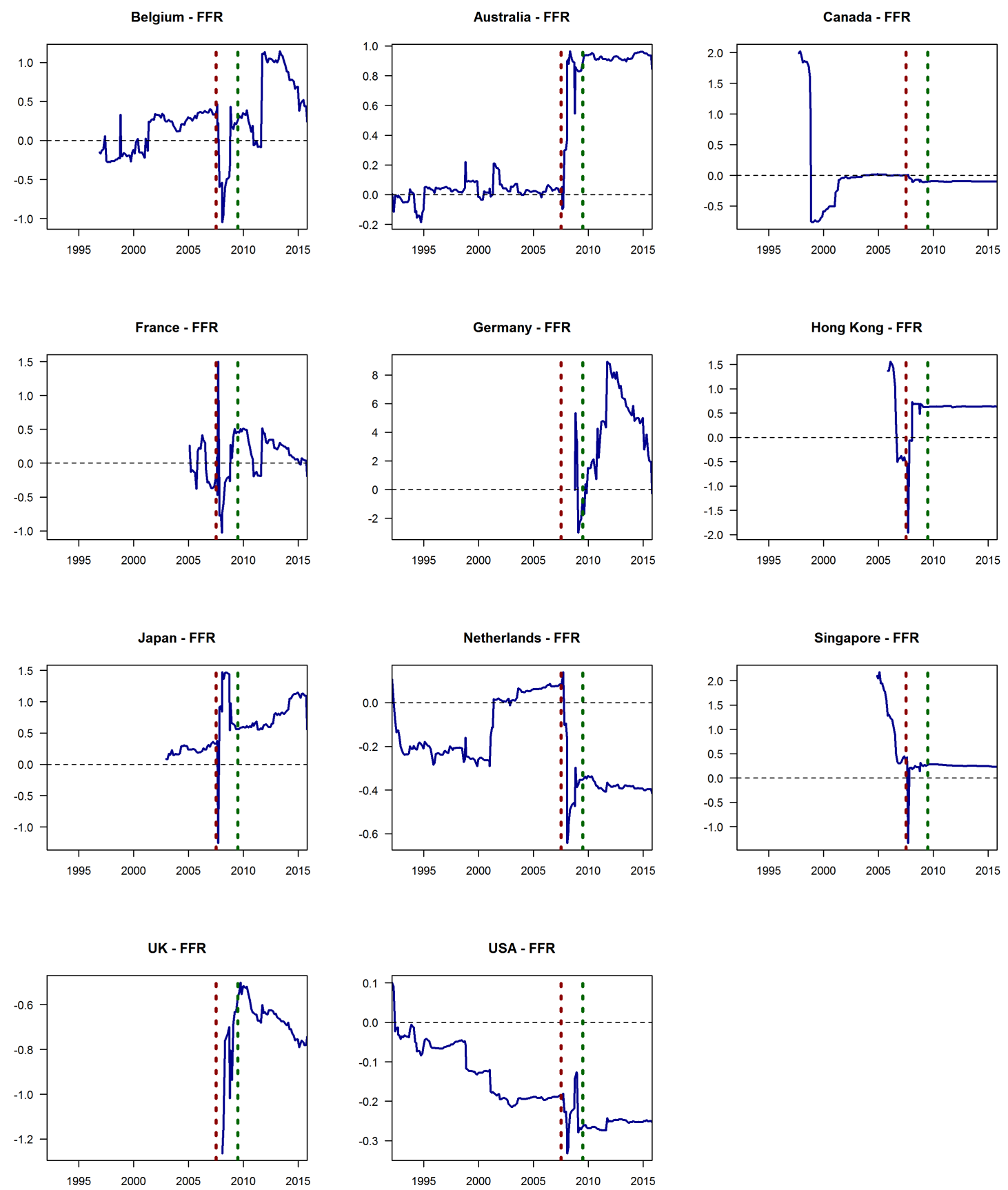

Figure 1. Time-varying impact of federal funds rate shocks. The plots show the time-varying response of international REITs to federal funds rate shocks. The period between the two vertical dotted lines capture the period of global financial crisis. 

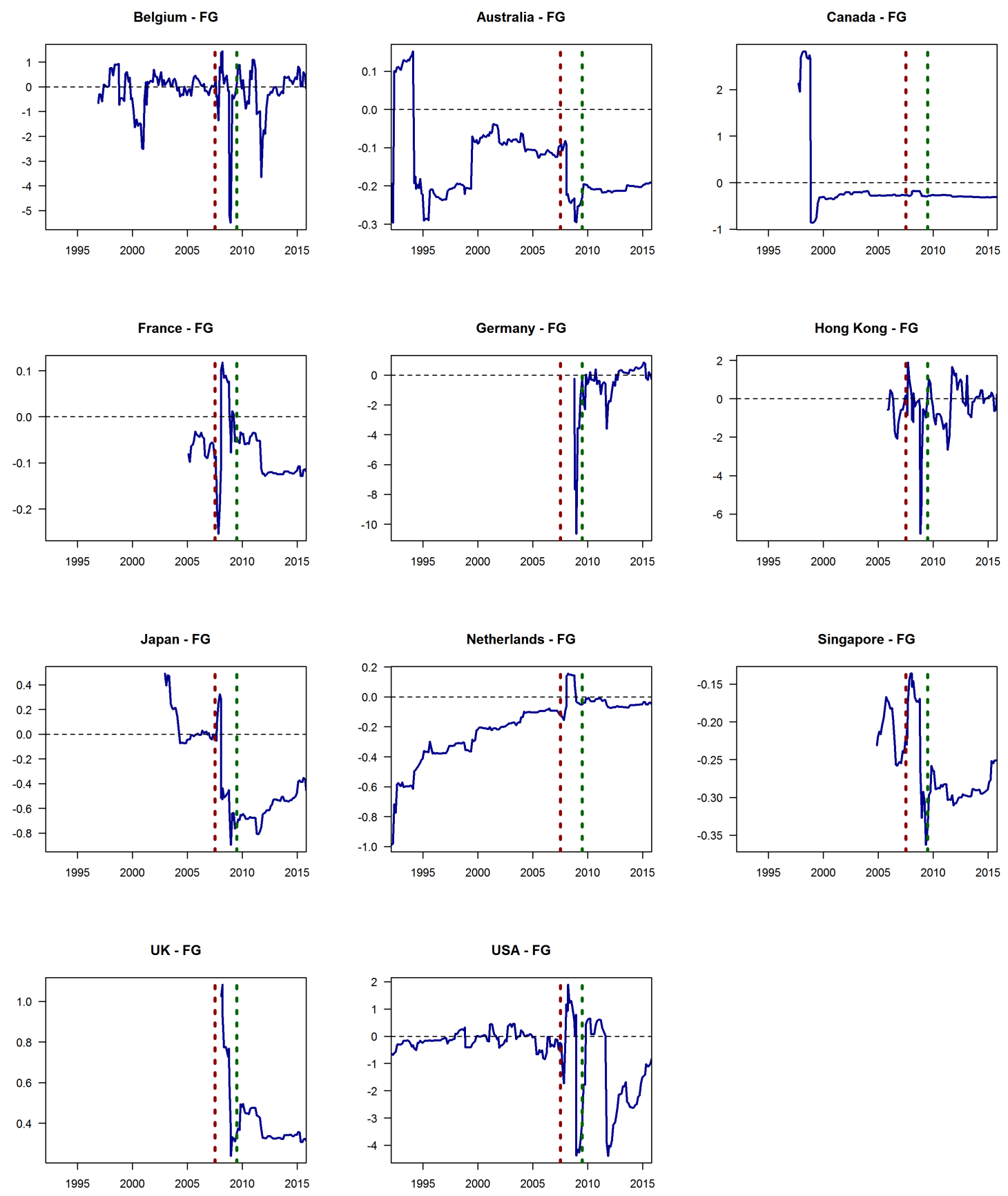

Figure 2. Time-varying impact of forward guidance shocks. The plots show the time-varying response of international REITs to forward guidance shocks. he period between the two vertical dotted lines capture the period of global financial crisis. 

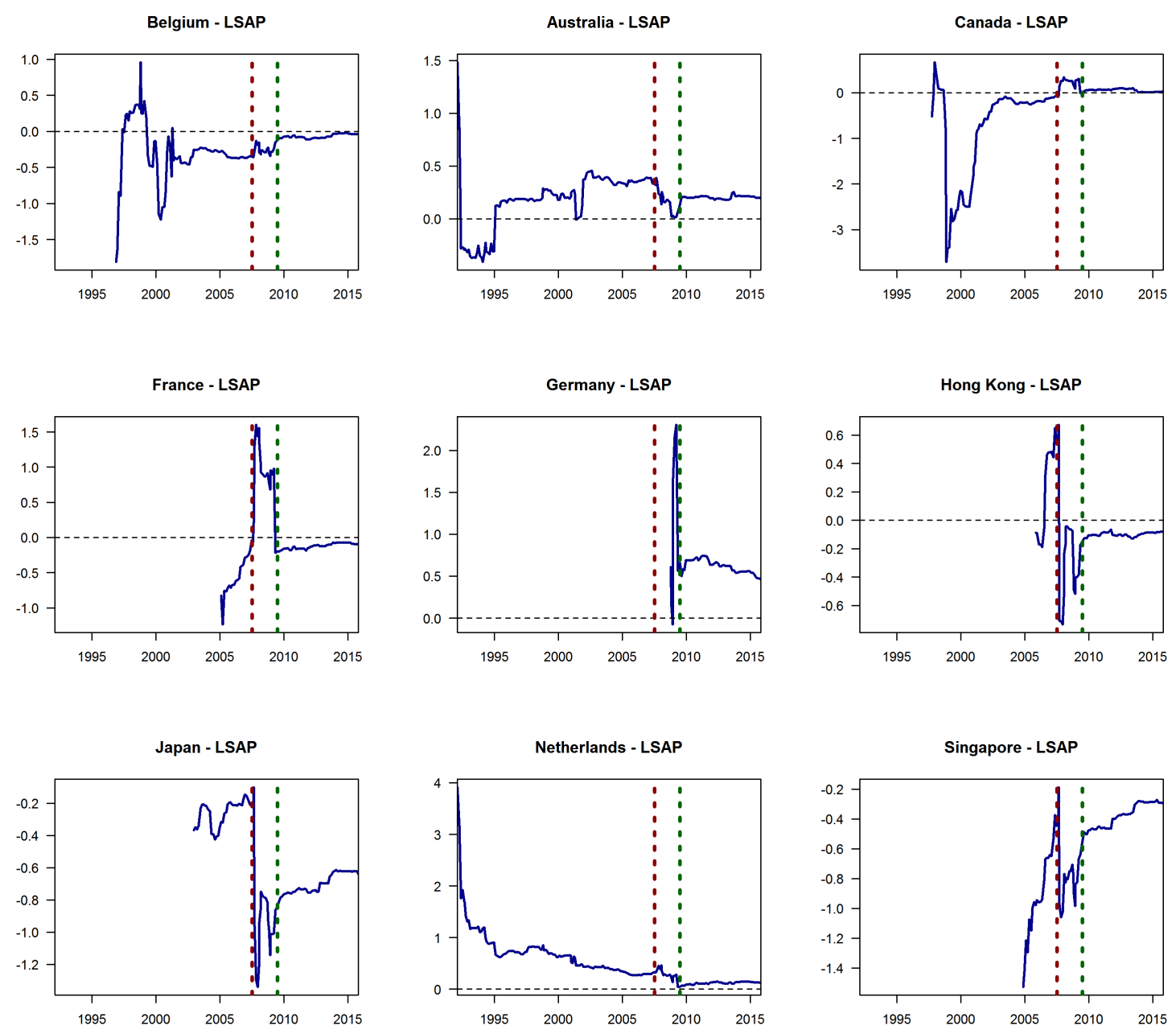

UK - LSAP

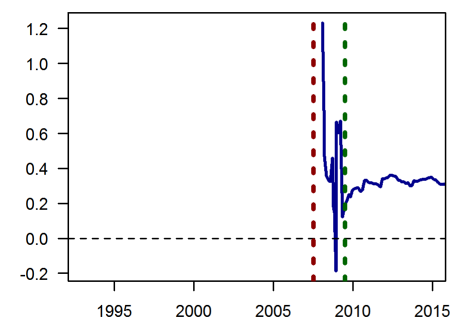

USA - LSAP

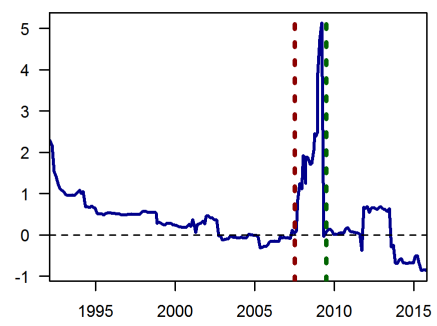

Figure 3. Time-varying impact of LSAP shocks. The plots show the time-varying response of international REITs to LSAP shocks. he period between the two vertical dotted lines capture the period of global financial crisis.

The impact of FG is negative for Asian REITs, specifically for Japan, Hong Kong, Singapore, and Australia. That is, unanticipated communication from the FOMC which for example said that it will keep interest rates unchanged at the zero lower bound "at least through mid-2015" in the 13 September 2012 FOMC meeting, signaled weak economic conditions to investors and Asian REIT investors were most sensitive to these signals. Moreover, the FOMC's FG during the period 2008-2014 mostly emphasized maintaining rates at the prevailing zero lower bound for longer. Yunus (2009) found the existence of a long-run interdependence between securitized property markets of the US and Asian countries of Japan and Hong Kong, as well as Australia and that the US was the source of 
common trends in these markets. In contrast, the European REITs were less responsive to FG shocks.

The dynamic effect of LSAP is shown in Figure 3. Evidence suggests that international REIT returns' response to LSAP is mixed. The effect on REITs was broadly negative for Belgium, Canada, and Japan over the full sample period with notably larger declines in the pre-GFC period with notably larger declines in Japan REITs returns. LSAP is intended to reduce longer-term interest rates or expectations of future short-term rates. Swanson (2021) found that the effect of LSAP announcements on stock prices was positive but not statistically significant. Earlier evidence by Rosa (2012) found that the surprise component of LSAP announcements boosted stock prices in the US. The coefficient of LSAP shocks is mostly positive in the US increased rapidly during the GFC before turning negative in the latter years after the GFC, while the effect in Germany and the UK were also positive across the sample periods, likewise, the coefficient is positive in Australia except prior to 1995. The expansion of LSAP increased REIT returns in these countries, reflecting the effects of portfolio re-balancing channel and in line with findings by Gabriel and Lutz (2017). LSAP reduces interest rates or yields on fixed-income assets inducing investors to re-weight their portfolios towards higher-yielding assets such REITs, supporting an increase in REIT prices. In the case of France, the impact was only positive during the GFC but negative before and after the GFC. However, the impact of LSAP is negative in the Asian markets of Japan and Singapore across the sample period and also mostly negative in Hong Kong but only during and after the GFC. The results for the respective Asian economies are similar to that of FG impact which showed negative effects. These results provide further motivation to delve into the nature of the relationship in the time-varying response of the three policy tools.

\subsection{Dynamic Impact, Gold Prices, Exchange Rates, Financial Conditions, and Market-Based Uncertainty}

Given the unique nature of conventional and unconventional policy tools, we now study the possible correlation in the response of REIT to these shocks. Table 2 presents the correlation between the time-varying response of international REIT to each monetary policy tool for each country. FG and LSAP policies are both a part of unconventional tools. Hence, we would expect the response of REITs to be similar. Interestingly, this is not the case for all the REIT markets.

In the case of Australia, Belgium, France, Hong Kong, and Japan, we find a strong positive correlation in the response of REIT shocks to FG and LSAP shocks. In these countries, an expansionary unconventional monetary shock raises REIT returns. These results are consistent with existing findings (Gabriel and Lutz 2017; Ghysels et al. 2013).In contrast, the time-varying impact of FG is inversely related to the time-varying impact of LSAP on REITs of Germany, the UK, and the United States. This suggests at least two things. First, unlike (Gabriel and Lutz 2017) and others, it is important to distinguish between the surprise changes in FG and LSAP, because these two policy tools have a very different impact on REIT returns. Second, in Germany, the UK, and the US, the monetary policy shocks transmit mostly through the signaling channel and the asset price channel.

In the case of the UK, US, and Germany, the dynamic impact of FG and LSAP on REITs are negatively correlated. The correlation coefficients range between -0.23 and -0.38 . In contrast, there is a strong positive correlation in the time-varying impact of LSAP and FG in the case of Australia (0.91) and Belgium (0.71). The correlation between the dynamic effect of FFR with the effect of FG and LSAP is mixed. The correlation is low with both the FG and LSAP in 9 of the 11 countries with the nature of correlation is generally mixed across the countries. Furthermore, the variance inflation factor (VIF) test for multicollinearity (not included in the table to maintain brevity) show FFR shocks and both the FG and LSAP shocks are all independent of each other with the results showing VIF values of 1.0 for each shock. 
Table 2. Correlation matrix: TVP impact. The table presents correlation matrix of the TVP response of REIT to each monetary policy shock, that is, federal funds rate (FFR), forward guidance, (FG), and large scale asset purchases (LSAP).

\begin{tabular}{|c|c|c|c|c|c|c|c|c|c|}
\hline & \multicolumn{3}{|c|}{ Australia } & \multicolumn{3}{|c|}{ Belgium } & \multicolumn{3}{|c|}{ Canada } \\
\hline & FFR & FG & LSAP & FFR & FG & LSAP & FFR & FG & LSAP \\
\hline FFR & 1.00 & & & 1.00 & & & 1.00 & & \\
\hline FG & 0.52 & 1.00 & & -0.04 & 1.00 & & 0.05 & 1.00 & \\
\hline \multirow[t]{2}{*}{ LSAP } & 0.62 & 0.91 & 1.00 & 0.28 & 0.71 & 1.00 & -0.06 & 0.43 & 1.00 \\
\hline & \multicolumn{3}{|c|}{ Germany } & \multicolumn{3}{|c|}{ France } & \multicolumn{3}{|c|}{ Hong Kong } \\
\hline & FFR & FG & LSAP & FFR & FG & LSAP & FFR & FG & LSAP \\
\hline FFR & 1.00 & & & 1.00 & & & 1.00 & & \\
\hline FG & 0.09 & 1.00 & & -0.06 & 1.00 & & -0.45 & 1.00 & \\
\hline \multirow[t]{3}{*}{ LSAP } & -0.33 & -0.30 & 1.00 & -0.06 & 0.52 & 1.00 & -0.17 & 0.67 & 1.00 \\
\hline & \multicolumn{3}{|c|}{ Japan } & \multicolumn{3}{|c|}{ Netherlands } & \multicolumn{3}{|c|}{ Singapore } \\
\hline & FFR & FG & LSAP & FFR & FG & LSAP & FFR & FG & LSAP \\
\hline FFR & 1.00 & & & 1.00 & & & 1.00 & & \\
\hline FG & 0.73 & 1.00 & & -0.07 & 1.00 & & -0.47 & 1.00 & \\
\hline \multirow[t]{3}{*}{ LSAP } & 0.56 & 0.63 & 1.00 & -0.27 & 0.30 & 1.00 & -0.28 & 0.07 & 1.00 \\
\hline & & UK & & & USA & & & & \\
\hline & FFR & FG & LSAP & FFR & FG & LSAP & & & \\
\hline FFR & 1.00 & & & 1.00 & & & & & \\
\hline FG & -0.01 & 1.00 & & -0.01 & 1.00 & & & & \\
\hline LSAP & 0.03 & -0.38 & 1.00 & 0.45 & -0.23 & 1.00 & & & \\
\hline
\end{tabular}

Next, we explore possible explanations for the time-varying response of REITs to policy shocks. Real estate investments are akin to gold in the sense of their function as a safe haven instrument (Akinsomi et al. 2016). Thus, we explore if gold price changes explain the time-varying response of REITs to conventional and unconventional monetary policy shocks. The exchange rate is the other key variable central to international REIT investments. At least in the case of the US, Ngo (2017) finds that the US dollar exchange rate significantly impacts US REIT returns. Hence, the other possibility is that a stronger or weaker currency of the country impacts the extent to which unexpected changes in monetary policy affect international REIT markets.

To study these effects, we regress the TVP coefficients on each of these two driversexchange rates and gold price changes. In each regression, we also include a constant and lagged value of the dependent variable to control for the model specification in Equation (3). Table 3 presents the regression results for each estimation. Evidence suggests that between exchange rates and gold, the latter holds more power to explain the timevariation in the impact of monetary policy on international REITs returns. Between the three policy instruments, the time-varying impact of FG shocks can be explained by changes in gold prices in 5 out of the 11 markets. One intuitive explanation for this could be the dynamics between the gold market and FG shocks. Forward guidance is the Fed's announcement of the future path of interest rates. In this sense, it aims to reduce the uncertainty amongst investors and economic agents. Gold price dynamics are also uncertainty-driven. Consequently, we find that gold price changes explain the time-varying impact of FG on international REITs returns. 
Table 3. The US financial market conditions and time-varying impact of federal funds shocks. The table presents the impact of the US financial market conditions on time-varying response of international REITs to federal funds shocks using the OLS model. Given the construction of the TVP model, each regression includes a lag of the dependent variable and a constant. The financial market condition measures include changes in gold prices, exchange rates, US treasury spread between 10-year and 3-month maturity, TED spread, spread between AAA corporate bond and 10-year treasury bond, spread between BAA corporate bond and 10-year treasury bond, and the VIX index.

\begin{tabular}{|c|c|c|c|c|c|c|c|c|c|c|c|c|}
\hline \multirow[b]{2}{*}{ Country } & \multicolumn{4}{|c|}{ Gold } & \multicolumn{4}{|c|}{ Exchange Rate } & \multicolumn{4}{|c|}{ Tr. Spread: 10 Year-3 Month } \\
\hline & Esti. & SE & P-Val & $\mathbf{R}^{2}$ & Esti. & SE & P-Val & $\mathbf{R}^{2}$ & Esti. & SE & P-Val & $\mathbf{R}^{2}$ \\
\hline Australia & 0.105 & 0.045 & 0.02 & 0.97 & -0.082 & 0.085 & 0.34 & 0.97 & -0.002 & 0.004 & 0.65 & 0.97 \\
\hline Belgium & 0.003 & 0.075 & 0.96 & 0.86 & -0.582 & 0.213 & 0.01 & 0.86 & 0.013 & 0.011 & 0.24 & 0.86 \\
\hline Canada & -0.066 & 0.059 & 0.26 & 0.91 & -0.015 & 0.198 & 0.94 & 0.91 & 0.009 & 0.010 & 0.37 & 0.91 \\
\hline Germany & 3.045 & 2.123 & 0.16 & 0.74 & -8.947 & 3.466 & 0.01 & 0.76 & -0.035 & 0.444 & 0.94 & 0.74 \\
\hline France & -0.331 & 0.322 & 0.31 & 0.26 & -0.474 & 0.486 & 0.33 & 0.26 & 0.056 & 0.030 & 0.07 & 0.30 \\
\hline Hong Kong & -5.045 & 1.508 & 0.00 & 0.75 & 0.250 & 0.431 & 0.56 & 0.71 & 0.067 & 0.028 & 0.02 & 0.74 \\
\hline Japan & -0.001 & 0.002 & 0.47 & 0.59 & -0.667 & 0.389 & 0.09 & 0.60 & 0.013 & 0.024 & 0.58 & 0.60 \\
\hline Netherlands & -0.058 & 0.025 & 0.02 & 0.94 & -0.135 & 0.059 & 0.02 & 0.93 & -0.001 & 0.003 & 0.65 & 0.93 \\
\hline Singapore & 0.079 & 0.202 & 0.70 & 0.84 & -0.039 & 0.321 & 0.90 & 0.84 & 0.004 & 0.020 & 0.85 & 0.84 \\
\hline UK & -0.030 & 0.077 & 0.70 & 0.69 & -0.402 & 0.127 & 0.00 & 0.73 & 0.013 & 0.015 & 0.39 & 0.71 \\
\hline \multirow[t]{2}{*}{ USA } & 0.016 & 0.044 & 0.73 & 0.69 & -0.023 & 0.022 & 0.30 & 0.96 & 0.000 & 0.001 & 0.75 & 0.96 \\
\hline & \multicolumn{4}{|c|}{ TED Spread } & \multicolumn{4}{|c|}{ Corp Spread: AAA10Y } & \multicolumn{4}{|c|}{ Corp Spread: BAA10Y } \\
\hline Country & Esti. & SE & P-Val & $\mathbf{R}^{2}$ & Esti. & SE & P-Val & $\mathbf{R}^{2}$ & Esti. & SE & P-Val & $\mathbf{R}^{2}$ \\
\hline Australia & 0.000 & 0.010 & 0.96 & 0.97 & 0.011 & 0.012 & 0.38 & 0.97 & 0.008 & 0.007 & 0.27 & 0.97 \\
\hline Belgium & -0.001 & 0.029 & 0.99 & 0.86 & 0.057 & 0.028 & 0.04 & 0.86 & 0.027 & 0.015 & 0.08 & 0.86 \\
\hline Canada & -0.028 & 0.022 & 0.21 & 0.91 & -0.020 & 0.027 & 0.45 & 0.91 & -0.009 & 0.015 & 0.56 & 0.91 \\
\hline Germany & 0.329 & 0.431 & 0.45 & 0.74 & -0.056 & 0.684 & 0.94 & 0.74 & -0.200 & 0.224 & 0.38 & 0.74 \\
\hline France & -0.053 & 0.055 & 0.34 & 0.28 & 0.119 & 0.064 & 0.07 & 0.30 & 0.055 & 0.033 & 0.11 & 0.29 \\
\hline Hong Kong & -0.045 & 0.046 & 0.33 & 0.72 & 0.126 & 0.062 & 0.05 & 0.73 & 0.043 & 0.031 & 0.17 & 0.72 \\
\hline Japan & -0.043 & 0.042 & 0.31 & 0.60 & 0.068 & 0.060 & 0.26 & 0.60 & 0.014 & 0.029 & 0.63 & 0.60 \\
\hline Netherlands & -0.002 & 0.007 & 0.82 & 0.93 & 0.003 & 0.008 & 0.72 & 0.93 & 0.001 & 0.004 & 0.90 & 0.93 \\
\hline Singapore & -0.044 & 0.034 & 0.19 & 0.84 & -0.020 & 0.048 & 0.69 & 0.84 & -0.007 & 0.024 & 0.78 & 0.84 \\
\hline UK & -0.043 & 0.013 & 0.00 & 0.75 & -0.028 & 0.029 & 0.35 & 0.71 & -0.003 & 0.010 & 0.75 & 0.70 \\
\hline \multirow[t]{2}{*}{ USA } & 0.005 & 0.003 & 0.04 & 0.96 & -0.005 & 0.003 & 0.11 & 0.96 & -0.004 & 0.002 & 0.03 & 0.96 \\
\hline & \multicolumn{4}{|c|}{ VIX } & & & & & & & & \\
\hline Country & Esti. & SE & P-Val & $\mathbf{R}^{2}$ & & & & & & & & \\
\hline Australia & 0.010 & 0.013 & 0.43 & 0.97 & & & & & & & & \\
\hline Belgium & 0.048 & 0.039 & 0.22 & 0.86 & & & & & & & & \\
\hline Canada & -0.030 & 0.032 & 0.36 & 0.91 & & & & & & & & \\
\hline Germany & 0.241 & 0.530 & 0.65 & 0.74 & & & & & & & & \\
\hline France & 0.071 & 0.078 & 0.36 & 0.28 & & & & & & & & \\
\hline Hong Kong & 0.038 & 0.070 & 0.59 & 0.72 & & & & & & & & \\
\hline Japan & -0.008 & 0.064 & 0.91 & 0.59 & & & & & & & & \\
\hline Netherlands & 0.001 & 0.009 & 0.95 & 0.93 & & & & & & & & \\
\hline Singapore & -0.053 & 0.054 & 0.33 & 0.84 & & & & & & & & \\
\hline UK & -0.010 & 0.020 & 0.62 & 0.70 & & & & & & & & \\
\hline USA & -0.002 & 0.003 & 0.55 & 0.96 & & & & & & & & \\
\hline
\end{tabular}

In nearly all cases, the two variables explain the time-varying impact of one or more monetary policy shocks. We find that bullion market cycles are synchronous with the effectiveness of FG. An increase (decrease) in gold prices increases (decreases) the impact of FG on REITs returns in the case of Belgium, Hong Kong, Singapore, and the United Kingdom. The results also show that the impact of changes in gold prices on the effectiveness of FFR has the opposite effect. That is in the cases of Hong Kong and the Netherlands where results are statistically significant. An increase (decrease) in gold prices decreases (increases) the time-varying impact of FFR on REITs in these respective countries. One possible explanation could be due to the inverse relationship between gold prices and interest rates. Increasing FFR raises the opportunity cost of holding non-yielding gold as an 
asset leading to a decline in gold prices. Therefore, a decrease in FFR will also be associated with rising gold prices, assuming everything else is constant. It is only in the case of Canada, Germany, and the US, that the time-varying impact of all the three monetary policy shocks are independent of exchange rates and gold price changes.

Finally, we explore potential linkages between financial market conditions and policy effectiveness. The intuition of this can be traced back to the Lucas (1973) island model. In this model, economic uncertainty is linked with aggregate demand shocks. In the case of other financial assets, studies find that financial market conditions are closely linked to the effectiveness of policy shocks on bonds (Marfatia 2015), stock (Marfatia 2014), and housing market (Caraiani et al. 2019). These studies find that higher uncertainty lowers the impact of monetary policy shocks. It is thus interesting to explore if a similar relationship exists between financial market conditions and the effectiveness of policy shocks on REITs.

We measure financial market conditions by credit risk or interest rate spreads and an uncertainty measure based on the stock market. The rate spreads considered are the US 10-year treasury to 3-month treasury bill which is the term spread, TED spread, the yield spread between AAA-rated corporate bond and the US 10-year treasury, the yield spread between BAA rated corporate bond and US 10-year treasury, and the volatility index (VIX).

We find strong evidence that credit risk spreads explain the time-varying impact of FG on international REITs shown in Table 4. The negative and statistically significant effect of monetary policy shocks on REIT is closely related to the US financial market conditions. This is the case for the term spread in 2 out of 11 markets, TED spread in 5 out of 11 markets, AAA10Y spread in 6 out of 11 markets, and BAA10Y spread with 7 out of 11 markets. These results are broadly consistent with evidence by Bredemeier et al. (2018) that an announcement of a reduction in current or future FFR tends to increase credit or interest rate spreads. Notably, in the case of corporate bond spreads, FG that reduces future FFR lowers long-term treasury yields relative to corporate bond yields which is why the spread increases. Corporate bonds yields fall by less compared to government bonds yields (Gürkaynak et al. 2005) in part because government bonds are more liquid. The VIX, a key measure of stock investors' sentiments, also explained negative FG effects in 5 out of 11 REIT markets.

In the case of the time-varying FFR effects, the evidence is mixed. For the term spread, as well as TED spread, the effects are statistically significant in 2 out of 11 markets. However, the term spread effects are positive while the TED spread effects are negative. The corporate bond spreads mostly explain positive FFR effects on REITs in the cases where effects are statistically significant ( 3 out of 11 countries for the AAA10Y spread) and (2 out of 11 countries for the BAA10Y spread). Giliberto and Shulman (2017) also found that increases in BAA corporate spreads are associated with an increase in REIT returns and that there is time variation in how REIT returns respond to the former. One possible explanation for this relationship is that FFR tightens financial conditions. This leads to higher credit spreads, and simultaneously REITs prices gain from higher interest rates because rental incomes increase.

The results are also mixed for the dynamic LSAP effects in Table 5. The term spread explains the time-varying impact of LSAP shocks on 4 out of 11 REIT markets, whereas the TED spread is positively related to policy impact in 3 out of 11 markets and negatively related in 2 out of 11 markets. Each of the corporate bond spreads explains LSAP effects in 3 out of 11 markets, respectively. The VIX is related to the dynamic impact of monetary policy shocks only in the case of the US.

To sum, we find that financial market conditions significantly influence the transmission of US monetary policy to international REITs, particularly the impact of FG shocks. Stock market uncertainty plays little or no role in explaining monetary policy effects on REITs, except in the case of FG shocks. FG shocks provide information to market participants about the likely future path of FFR over the next several quarters or years. This shapes market expectations not only about interest rates but also about future economic conditions. Because this reduces uncertainty, we find that the effectiveness of FG on the 
international REIT markets is closely related to the VIX. This possibly explains why the VIX matters for FG shocks rather than FFR and LSAP shocks.

Table 4. The US financial market conditions and time-varying impact of forward guidance shocks. The table presents the impact of the US financial market conditions on time-varying response of international REITs to forward guidance shocks using the OLS model. Given the construction of the TVP model, each regression includes a lag of the dependent variable and a constant. The financial market condition measures include changes in gold prices, exchange rates, US treasury spread between 10-year and 3-month maturity, TED spread, spread between AAA corporate bond and 10-year treasury bond, spread between BAA corporate bond and 10-year treasury bond, and the VIX index.

\begin{tabular}{|c|c|c|c|c|c|c|c|c|c|c|c|c|}
\hline \multirow[b]{2}{*}{ Country } & \multicolumn{4}{|c|}{ Gold } & \multicolumn{4}{|c|}{ Exchange Rate } & \multicolumn{4}{|c|}{ Spread: 10 Year-3 Month } \\
\hline & Esti. & SE & P-Val & $\mathbf{R}^{2}$ & Esti. & SE & P-Val & $\mathbf{R}^{2}$ & Esti. & SE & P-Val & $\mathbf{R}^{2}$ \\
\hline Australia & -0.034 & 0.022 & 0.13 & 0.83 & 0.031 & 0.052 & 0.56 & 0.83 & 0.001 & 0.002 & 0.79 & 0.83 \\
\hline Belgium & 0.100 & 0.338 & 0.77 & 0.51 & 1.878 & 0.910 & 0.04 & 0.52 & 0.003 & 0.048 & 0.96 & 0.52 \\
\hline Canada & -0.027 & 0.114 & 0.81 & 0.84 & -0.100 & 0.371 & 0.79 & 0.84 & -0.001 & 0.019 & 0.95 & 0.84 \\
\hline Germany & -0.448 & 2.123 & 0.83 & 0.47 & 6.435 & 3.554 & 0.08 & 0.50 & -0.193 & 0.326 & 0.56 & 0.49 \\
\hline France & 0.064 & 0.034 & 0.06 & 0.78 & 0.078 & 0.049 & 0.12 & 0.78 & 0.001 & 0.003 & 0.83 & 0.78 \\
\hline Hong Kong & 3.003 & 5.085 & 0.56 & 0.40 & 4.886 & 1.493 & 0.00 & 0.47 & -0.108 & 0.096 & 0.26 & 0.42 \\
\hline Japan & 0.002 & 0.001 & 0.11 & 0.92 & 0.076 & 0.143 & 0.60 & 0.92 & -0.019 & 0.009 & 0.04 & 0.93 \\
\hline Netherlands & 0.053 & 0.016 & 0.00 & 0.95 & 0.022 & 0.039 & 0.58 & 0.98 & 0.002 & 0.002 & 0.29 & 0.98 \\
\hline Singapore & 0.015 & 0.016 & 0.36 & 0.89 & 0.084 & 0.026 & 0.00 & 0.90 & -0.004 & 0.002 & 0.05 & 0.89 \\
\hline UK & 0.209 & 0.073 & 0.01 & 0.92 & 0.237 & 0.092 & 0.01 & 0.92 & 0.010 & 0.010 & 0.34 & 0.91 \\
\hline \multirow[t]{2}{*}{ USA } & -0.813 & 1.632 & 0.62 & 0.73 & 0.343 & 0.687 & 0.62 & 0.78 & 0.002 & 0.033 & 0.96 & 0.78 \\
\hline & \multicolumn{4}{|c|}{ TED Spread } & \multicolumn{4}{|c|}{ AAA10Y } & \multicolumn{4}{|c|}{ BAA10Y } \\
\hline Country & Esti. & $\mathrm{SE}$ & P-Val & $\mathbf{R}^{2}$ & Esti. & SE & P-Val & $\mathbf{R}^{2}$ & Esti. & SE & P-Val & $\mathbf{R}^{2}$ \\
\hline Australia & -0.008 & 0.006 & 0.19 & 0.84 & -0.002 & 0.006 & 0.73 & 0.83 & -0.002 & 0.003 & 0.50 & 0.83 \\
\hline Belgium & -0.345 & 0.105 & 0.00 & 0.55 & -0.232 & 0.122 & 0.06 & 0.53 & -0.175 & 0.070 & 0.01 & 0.53 \\
\hline Canada & -0.019 & 0.042 & 0.65 & 0.84 & -0.043 & 0.050 & 0.39 & 0.84 & -0.025 & 0.028 & 0.36 & 0.84 \\
\hline Germany & -3.113 & 0.304 & 0.00 & 0.82 & -3.678 & 0.741 & 0.00 & 0.64 & -1.711 & 0.256 & 0.00 & 0.72 \\
\hline France & 0.002 & 0.006 & 0.77 & 0.78 & 0.001 & 0.007 & 0.92 & 0.77 & 0.000 & 0.004 & 0.99 & 0.77 \\
\hline Hong Kong & -0.384 & 0.161 & 0.02 & 0.45 & -0.176 & 0.226 & 0.44 & 0.42 & -0.209 & 0.119 & 0.08 & 0.43 \\
\hline Japan & -0.015 & 0.015 & 0.33 & 0.93 & -0.068 & 0.023 & 0.00 & 0.93 & -0.032 & 0.011 & 0.00 & 0.93 \\
\hline Netherlands & -0.002 & 0.005 & 0.65 & 0.98 & -0.001 & 0.005 & 0.79 & 0.98 & -0.002 & 0.003 & 0.53 & 0.98 \\
\hline Singapore & -0.007 & 0.003 & 0.05 & 0.89 & -0.012 & 0.004 & 0.00 & 0.90 & -0.008 & 0.002 & 0.00 & 0.91 \\
\hline UK & -0.022 & 0.011 & 0.05 & 0.92 & -0.050 & 0.019 & 0.01 & 0.92 & -0.019 & 0.006 & 0.00 & 0.92 \\
\hline \multirow[t]{2}{*}{ USA } & -0.073 & 0.082 & 0.37 & 0.78 & -0.194 & 0.081 & 0.02 & 0.79 & -0.148 & 0.046 & 0.00 & 0.79 \\
\hline & \multicolumn{4}{|c|}{ VIX } & & & & & & & & \\
\hline Country & Esti. & SE & P-Val & $\mathbf{R}^{2}$ & & & & & & & & \\
\hline Australia & -0.008 & 0.008 & 0.30 & 0.84 & & & & & & & & \\
\hline Belgium & -0.442 & 0.155 & 0.01 & 0.54 & & & & & & & & \\
\hline Canada & -0.010 & 0.061 & 0.87 & 0.84 & & & & & & & & \\
\hline Germany & -3.049 & 0.503 & 0.00 & 0.69 & & & & & & & & \\
\hline France & 0.001 & 0.009 & 0.89 & 0.77 & & & & & & & & \\
\hline Hong Kong & -0.418 & 0.265 & 0.12 & 0.43 & & & & & & & & \\
\hline Japan & -0.053 & 0.023 & 0.03 & 0.93 & & & & & & & & \\
\hline Netherlands & -0.004 & 0.006 & 0.50 & 0.98 & & & & & & & & \\
\hline Singapore & -0.012 & 0.004 & 0.01 & 0.90 & & & & & & & & \\
\hline UK & -0.027 & 0.015 & 0.08 & 0.92 & & & & & & & & \\
\hline USA & -0.172 & 0.104 & 0.10 & 0.78 & & & & & & & & \\
\hline
\end{tabular}


Table 5. The US financial market conditions and time-varying impact of LSAP shocks. The table presents the impact of the US financial market conditions on time-varying response of international REITs to LSAP shocks using the OLS model. Given the construction of the TVP model, each regression includes a lag of the dependent variable and a constant. The financial market condition measures include changes in gold prices, exchange rates, US treasury spread between 10-year and 3-month maturity, TED spread, spread between AAA corporate bond and 10-year treasury bond, spread between BAA corporate bond and 10-year treasury bond, and the VIX index.

\begin{tabular}{|c|c|c|c|c|c|c|c|c|c|c|c|c|}
\hline \multirow[b]{2}{*}{ Country } & \multicolumn{4}{|c|}{ Gold } & \multicolumn{4}{|c|}{ Exchange Rate } & \multicolumn{4}{|c|}{ Spread: 10 Year-3 Month } \\
\hline & Esti. & SE & P-Val & $\mathbf{R}^{2}$ & Esti. & SE & P-Val & $\mathbf{R}^{2}$ & Esti. & SE & P-Val & $\mathbf{R}^{2}$ \\
\hline Australia & -0.001 & 0.048 & 0.98 & 0.79 & 0.017 & 0.121 & 0.89 & 0.79 & -0.017 & 0.006 & 0.00 & 0.80 \\
\hline Belgium & 0.130 & 0.063 & 0.04 & 0.67 & -0.215 & 0.211 & 0.31 & 0.70 & 0.000 & 0.011 & 0.99 & 0.70 \\
\hline Canada & -0.215 & 0.134 & 0.11 & 0.90 & -0.164 & 0.365 & 0.65 & 0.90 & 0.016 & 0.021 & 0.43 & 0.90 \\
\hline Germany & 0.443 & 0.417 & 0.29 & 0.28 & 1.408 & 0.683 & 0.04 & 0.31 & -0.043 & 0.065 & 0.52 & 0.29 \\
\hline France & 0.216 & 0.225 & 0.34 & 0.88 & 0.298 & 0.299 & 0.32 & 0.88 & -0.038 & 0.018 & 0.04 & 0.88 \\
\hline Hong Kong & 1.688 & 0.919 & 0.07 & 0.65 & -0.225 & 0.253 & 0.38 & 0.63 & -0.025 & 0.017 & 0.15 & 0.65 \\
\hline Japan & 0.000 & 0.001 & 0.90 & 0.87 & -0.162 & 0.148 & 0.28 & 0.87 & 0.003 & 0.010 & 0.74 & 0.88 \\
\hline Netherlands & -0.020 & 0.023 & 0.39 & 0.96 & 0.008 & 0.127 & 0.95 & 0.95 & -0.013 & 0.006 & 0.03 & 0.95 \\
\hline Singapore & -0.242 & 0.113 & 0.03 & 0.88 & -0.194 & 0.156 & 0.22 & 0.87 & 0.006 & 0.010 & 0.52 & 0.87 \\
\hline UK & 0.015 & 0.115 & 0.89 & 0.08 & -0.048 & 0.218 & 0.83 & 0.08 & -0.050 & 0.023 & 0.03 & 0.17 \\
\hline \multirow[t]{2}{*}{ USA } & -1.206 & 1.203 & 0.32 & 0.71 & 0.532 & 0.507 & 0.30 & 0.75 & -0.014 & 0.025 & 0.57 & 0.75 \\
\hline & \multicolumn{4}{|c|}{ TED Spread } & \multicolumn{4}{|c|}{ AAA10Y } & \multicolumn{4}{|c|}{ BAA10Y } \\
\hline Country & Esti. & SE & P-Val & $\mathbf{R}^{2}$ & Esti. & SE & P-Val & $\mathbf{R}^{2}$ & Esti. & SE & P-Val & $\mathbf{R}^{2}$ \\
\hline Australia & -0.010 & 0.014 & 0.49 & 0.79 & 0.012 & 0.014 & 0.39 & 0.79 & 0.006 & 0.008 & 0.47 & 0.79 \\
\hline Belgium & 0.009 & 0.024 & 0.71 & 0.70 & -0.001 & 0.027 & 0.96 & 0.70 & -0.006 & 0.015 & 0.68 & 0.70 \\
\hline Canada & -0.036 & 0.041 & 0.39 & 0.90 & 0.004 & 0.048 & 0.94 & 0.90 & 0.003 & 0.027 & 0.90 & 0.90 \\
\hline Germany & 0.057 & 0.083 & 0.50 & 0.29 & 0.409 & 0.132 & 0.00 & 0.39 & 0.104 & 0.043 & 0.02 & 0.35 \\
\hline France & 0.097 & 0.041 & 0.02 & 0.89 & -0.059 & 0.047 & 0.21 & 0.88 & -0.042 & 0.025 & 0.10 & 0.88 \\
\hline Hong Kong & -0.061 & 0.026 & 0.02 & 0.66 & -0.094 & 0.043 & 0.03 & 0.66 & -0.037 & 0.021 & 0.08 & 0.65 \\
\hline Japan & -0.048 & 0.016 & 0.00 & 0.89 & -0.026 & 0.031 & 0.41 & 0.88 & -0.012 & 0.015 & 0.41 & 0.88 \\
\hline Netherlands & 0.009 & 0.015 & 0.53 & 0.95 & -0.031 & 0.016 & 0.05 & 0.95 & -0.024 & 0.009 & 0.01 & 0.95 \\
\hline Singapore & -0.045 & 0.016 & 0.01 & 0.88 & 0.010 & 0.022 & 0.63 & 0.87 & -0.001 & 0.011 & 0.94 & 0.87 \\
\hline UK & -0.017 & 0.020 & 0.40 & 0.12 & 0.050 & 0.045 & 0.28 & 0.12 & 0.004 & 0.015 & 0.80 & 0.11 \\
\hline \multirow[t]{2}{*}{ USA } & 0.281 & 0.065 & 0.00 & 0.77 & 0.037 & 0.061 & 0.54 & 0.75 & 0.044 & 0.037 & 0.24 & 0.76 \\
\hline & \multicolumn{4}{|c|}{ VIX } & & & & & & & & \\
\hline Country & Esti. & SE & P-Val & $\mathbf{R}^{2}$ & & & & & & & & \\
\hline Australia & 0.021 & 0.018 & 0.25 & 0.80 & & & & & & & & \\
\hline Belgium & 0.006 & 0.035 & 0.86 & 0.70 & & & & & & & & \\
\hline Canada & -0.032 & 0.060 & 0.59 & 0.90 & & & & & & & & \\
\hline Germany & 0.125 & 0.097 & 0.20 & 0.31 & & & & & & & & \\
\hline France & -0.005 & 0.061 & 0.93 & 0.88 & & & & & & & & \\
\hline Hong Kong & -0.072 & 0.044 & 0.11 & 0.65 & & & & & & & & \\
\hline Japan & -0.041 & 0.029 & 0.16 & 0.88 & & & & & & & & \\
\hline Netherlands & -0.010 & 0.019 & 0.61 & 0.95 & & & & & & & & \\
\hline Singapore & -0.018 & 0.025 & 0.46 & 0.87 & & & & & & & & \\
\hline UK & -0.033 & 0.032 & 0.31 & 0.12 & & & & & & & & \\
\hline USA & 0.161 & 0.081 & 0.05 & 0.76 & & & & & & & & \\
\hline
\end{tabular}

\section{Conclusions}

The dynamic role of unconventional monetary policy in driving international REIT returns is unexplored in the existing literature and this paper makes a contribution to the literature in this regard by estimating the time-varying impact of both conventional and unconventional US monetary policy on global REIT returns based on an event study framework and time-varying parameter model. To the best of our knowledge, this is the first paper investigating dynamic shocks of US monetary policy both conventional and unconventional on global REITs. Unconventional monetary policy in the form of FG and LSAP is believed to affect asset prices including REITs through the signaling and portfolio-rebalancing channels. This paper distinguishes the individual impact of FFR, 
FG, and LSAP on global REITs and shows how these effects have evolved over time. We further attempt REIT to explain the drivers of the REIT responses to all three US monetary policy shocks.

Our findings are that the response of international REITs to monetary policy shocks varies over time and across the countries. Secondly, FFR shocks broadly have a positive impact on REITs in more than half the countries in our sample and suggests both the signaling and borrowing channels are at play. In terms of unconventional monetary policy tools, FG tended to have a negative relationship with REITs particularly in Asian and European REIT markets meaning the FOMC's communication, mostly over the period 2008-2014, that the FFR will remain at the zero lower bound implied economic conditions will remain weak which influenced investor's own expectations with implications for REITs. We also find evidence that the dynamic response of REITs to monetary policy shocks can be explained by changes in gold prices, financial market conditions, and, to a lesser extent, financial market uncertainty. In particular, increases in the gold price raise the impact of FG shocks on dynamic REITs and these findings are not surprising given uncertainty or certainty drives the dynamics of both FG and gold prices. Gold price changes have little effect on FFR impact on REITs. In the US, Canada, and Germany, both exchange rate and gold price changes could not explain the effect of monetary policy shocks on REITs. Financial market conditions, measured by credit risk spreads, also explain the impact of FG on REITs, and this influence is relatively strong. Wider credit spreads reduces the dynamic effect of FG on global REITs. The results for the FFR and LSAP cases are mixed in this regard. Financial market uncertainty proxied by the VIX explains FG shocks but only in the US.

Author Contributions: Conceptualization, H.A.M. and R.G.; methodology, H.A.M.; software, H.A.M.; validation, H.A.M., R.G. and K.L.; formal analysis, K.L.; writing-original draft preparation, K.L.; writing-review and editing, H.A.M.; supervision, R.G.; project administration, R.G. All authors have read and agreed to the published version of the manuscript.

Funding: This research received no external funding.

Institutional Review Board Statement: Not applicable.

Informed Consent Statement: Not applicable.

Data Availability Statement: The data that support the findings of this study are openly available in Datastream and Krippner (2013).

Conflicts of Interest: The authors declare no conflict of interest.

\section{Notes}

1 The event study approach is one of the most superior approaches because it addresses the two most challenging problems in assessing monetary policy impact, namely, identification and endogeneity. Several studies use this approach including, Cook and Hahn (1989), Kuttner (2001), Bernanke and Kuttner (2005), and Hausman and Wongswan (2011), Marfatia (2014, 2015), Nyakabawo et al. (2018), and Gupta et al. (2019).

2 An overview of key developments can be found in publications of the European Public Real Estate Association.

\section{References}

Akinsomi, Omokolade, Goodness C. Aye, Vassilios Babalos, Fotini Economou, and Rangan Gupta. 2016. Real estate returns predictability revisited: Novel evidence from the US REITs market. Empirical Economics 51: 1165-90. [CrossRef]

Batrancea, Ioan, Larissa Batrancea, Malar Maran Rathnaswamy, Horia Tulai, Gheorghe Fatacean, and Mircea-Iosif Rus. 2020. Greening the Financial System in USA, Canada and Brazil: A Panel Data Analysis. Mathematics 8: 2217. [CrossRef]

Bauer, Michael, and Glenn D. Rudebusch. 2014. The Signaling Channel for Federal Reserve Bond Purchases. International Journal of Central Banking 10: 233-89. [CrossRef]

Bauer, Michael D., and Christopher J. Neely. 2014. International channels of the Fed's unconventional monetary policy. Journal of International Money and Finance 44: 24-46. [CrossRef]

Bernanke, Ben S., and Kenneth N. Kuttner. 2005. What explains the stock market's reaction to Federal Reserve policy? The Journal of Finance 60: 1221-257. [CrossRef] 
Bredemeier, Christian, Christoph Kaufmann, and Andreas Schabert. 2018. Interest Rate Spreads and Forward Guidance. Working Paper Series 2186; Frankfurt: European Central Bank.

Bredin, Don, Gerard O'Reilly, and Simon Stevenson. 2010. Monetary policy transmission and real estate investment trusts. International Journal of Finance \& Economics 16: 92-102.

Caraiani, Petre, Rangan Gupta, Chi Keung Marco Lau, and Hardik Arvind Marfatia. 2019. Effects of Conventional and Unconventional Monetary Policy Shocks on Housing Prices in the United States: The Role of Sentiment. Working No. 201953. Pretoria: Department of Economics, University of Pretoria.

Chan, Su Han, Wai-Kin Leung, and Ko Wang. 2005. Changes in REIT Structure and Stock Performance, Evidence from the Monday Stock Anomaly. Real Estate Economics 33: 89-120. [CrossRef]

Chian, Thomas Chinan. 2020. Global Stock Market Prices Response to Uncertainty Changes in US Monetary and Fiscal Policies. In Emerging Market Finance: New Challenges and Opportunities (International Finance Review, Vol. 21). Edited by Bang Nam Jeon and Ji Wu. Bingley: Emerald Publishing Limited, pp. 131-47.

Chou, Yu-Hsi, and Yi-Chi Chen. 2014. Is the Response of REIT Returns to Monetary Policy Asymmetric? Journal of Real Estate Research, American Real Estate Society 36: 109-36. [CrossRef]

Claus, Edda, Iris Claus, and Leo Krippner. 2014. Asset Markets and Monetary Policy Shocks at the Zero Lower Bound. Technical Report. Canberra: Centre for Applied Macroeconomic Analysis, Crawford School of Public Policy, The Australian National University.

Cook, Timothy, and Thomas Hahn. 1989. The effect of changes in the federal funds rate target on market interest rates in the 1970s. Journal of Monetary Economics 24: 331-51. [CrossRef]

Cooley, Thomas F., and Edward C. Prescott. 1976. Estimation in the presence of stochastic parameter variation. Econometrica: Journal of the Econometric Society 44: 167-84. [CrossRef]

European Public Real Estate Associaion (EPRA). 2016. Global REIT Survey 2016. Brussels: European Public Real Estate Associaion

Feldkircher, Martin, and Florian Huber. 2018. Unconventional U.S. Monetary Policy: New Tools, Same Channels? Journal of Risk and Financial Management 11: 71. [CrossRef]

Gabriel, Stuart A., and Chandler Lutz. 2017. The Impact of Unconventional Monetary Policy on Real Estate Markets. SSRN 2493873. Available online: https:/ / ssrn.com/abstract=2493873 (accessed on 30 June 2020).

Gagnon, Joseph, Matthew Raskin, Julie Remache, and Brian Sack. 2011. The Financial Market Effects of the Federal Reserve's Large-Scale Asset Purchases. International Journal of Central Banking 7: 3-43.

Ghysels, Eric, Alberto Plazzi, Rossen Valkanov, and Walter Torous. 2013. Forecasting Real Estate Prices. In Handbook of Economic Forecasting. Amsterdam: Elsevier, vol. 2, pp. 509-80.

Giliberto, Michael, and David Shulman. 2017. On the Interest Rate Sensitivity of REITs: Evidence from Twenty Years of Daily Data. Journal of Real Estate Portfolio Management 23: 7-20. [CrossRef]

Gray, Colin. 2013. Responding to a Monetary Superpower: Investigating the Behavioral Spillovers of U.S. Monetary Policy. Atlantic Economic Journal 41: 173-84. [CrossRef]

Gupta, Rangan, and Hardik A. Marfatia. 2018. The impact of unconventional monetary policy shocks in the US on emerging market REITs. Journal of Real Estate Literature 26: 175-88. [CrossRef]

Gupta, Rangan, Chi Keng Marco Lau, Ruipeng Liu, and Hardik A. Marfatia. 2019. Price jumps in developed stock markets: The role of monetary policy committee meetings. Journal of Economics and Finance 43: 298-312. [CrossRef]

Gürkaynak, Refet S., Brian Sack, and Eric T. Swanson. 2005. Do Actions Speak Louder Than Words? The Response of Asset Prices to Monetary Policy Actions and Statements. International Journal of Central Banking 1: 55-93.

Haldane, Andrew, Matt Roberts-Sklar, Tomasz Wieladek, and Chris Young. 2016. QE: The Story So Far. Bank of England Working Papers 624. London: Bank of England.

Hausman, Joshua, and Jon Wongswan. 2011. Global asset prices and FOMC announcements. Journal of International Money and Finance 30: 547-71. [CrossRef]

Hesse, Henning, Boris Hofmann, and James Michael Weber. 2018. The macroeconomic effects of asset purchases revisited. Journal of Macroeconomics 58: 115-38. [CrossRef]

Huber, Florian, and Maria Teresa Punzi. 2018. International Housing Markets, Unconventional Monetary Policy and the Zero Lower Bound. Macroeconomic Dynamics 24: 774-806. [CrossRef]

Kishor, N. Kundan, and Hardik A. Marfatia. 2013. The time-varying response of foreign stock markets to US monetary policy surprises: Evidence from the Federal funds futures market. Journal of International Financial Markets, Institutions and Money 24: 1-24. [CrossRef]

Krippner, Leo. 2013. Measuring the stance of monetary policy in zero lower bound environmentst. Economics Letters 118: 135-38. [CrossRef]

Kuttner, Kenneth N. 2001. Monetary policy surprises and interest rates: Evidence from the Fed funds futures market. Journal of Monetary Economics 47: 523-44. [CrossRef]

Lubik, Thomas A., and Christian Matthes. 2015. Time-varying parameter vector autoregressions: Specification, estimation, and an application. Economic Quarterly-Federal Reserve Bank of Richmond 101: 323. [CrossRef]

Lucas, Robert E. 1973. Some International Evidence on Output-Inflation Tradeoff. The American Economic Review 63: 326-34.

Marfatia, Hardik A. 2014. Impact of uncertainty on high frequency response of the US stock markets to the Fed's policy surprises. The Quarterly Review of Economics and Finance 54: 382-92. [CrossRef] 
Marfatia, Hardik A. 2015. Monetary policy's time-varying impact on the US bond markets: Role of financial stress and risks. The North American Journal of Economics and Finance 34: 103-23. [CrossRef]

Marfatia, Hardik A., Rangan Gupta, and Esin Cakan. 2017. The international REIT's time-varying response to the US monetary policy and macroeconomic surprises. The North American Journal of Economics and Finance 42: 640-53. [CrossRef]

Miranda-Agrippino, Silvia, and Hélène Rey. 2020. US Monetary Policy and the Global Financial Cycle. Review of Economic Studies 86: 2754-76. [CrossRef]

Nakamura, Emi, and Jón Steinsson. 2018. High-frequency identification of monetary non-neutrality: The information effect. The Quarterly Journal of Economics 133: 1283-330. [CrossRef]

Ngo, Thanh. 2017. Exchange rate exposure of REITs. The Quarterly Review of Economics and Finance 64: 249-58. [CrossRef]

Nyakabawo, Wendy, Rangan Gupta, and Hardik A. Marfatia. 2018. High frequency impact of monetary policy and macroeconomic surprises on US MSAs, aggregate US housing returns and asymmetric volatility. Advances in Decision Sciences 22: 1-25.

Refinitiv. 2020. Datastream International. Available online: https:/ / www.refinitiv.com/ (accessed on 30 June 2020).

Rosa, Carlo. 2012. How 'Unconventional' Are Large-Scale Asset Purchases? The Impact of Monetary Policy on Asset Prices. FRB of New York Staff Report 560. Available online: https:/ / ssrn.com/abstract=2053640 (accessed on 30 June 2020).

Sahoo, Satyananda, Shiv Shanker, and Jessica M. Anthony. 2020. US Monetary Policy and Spillovers to Select EMEs: An Episodic Analysis. In Financial Issues in Emerging Economies: Special Issue Including Selected Papers from II International Conference on Economics and Finance, 2019, Bengaluru, India (Research in Finance, Vol. 36). Edited by Rita Biswas and Michael Michaelides. Bingley: Emerald Publishing Limited, pp. 67-97.

Smith, A. Lee, and Thealexa Becker. 2015. Has Forward Guidance been Effective? In Economic Review. Kansas City: Federal Reserve Bank of Kansas City, p. 57.

Swanson, Eric T. 2021. Measuring the Effects of Federal Reserve Forward Guidance and Asset Purchases on Financial Markets. Journal of Monetary Economics 118: 32-53. [CrossRef]

Xu, Pisun, and Jian Yang. 2011. US monetary policy surprises and international securitized real estate markets. The Journal of Real Estate Finance and Economics 43: 459-90. [CrossRef]

Yunus, Nafeesa. 2009. Increasing convergence between US and international securitized property market: Evidence based on cointegration tests. Real Estate Economics 37: 383-411. [CrossRef] 